\title{
World trends in the development of the LNG industry
}

\author{
L V Vazhenina \\ Tyumen Industrial University \\ 625001, Tyumen, Volodarskogo St., 38 \\ Tyumen, Russia \\ Vagenina@rambler.ru
}

\begin{abstract}
In modern geopolitical conditions, the processes of international hydrocarbon trade are becoming more complicated. World trends dictate the development of new solutions and adaptation to the external environment. The key factors contributing to the development of the global gas market are the shift in priorities towards environmentally friendly energy sources; greater opportunities for transport of liquefied natural gas, compared to pipeline gas transport, which has significant geopolitical risks; the ability to meet emerging gas demand during peak demand periods.
\end{abstract}

The article looks at the prospects for the development of the LNG industry in the Russian and world markets. Since the technologies for liquefying natural gas are technologically simple and cost-effective, they therefore open up broad prospects for the development of international gas trade.

The study examined the place and the role of LNG production in the world and in Russia. The volumes of LNG export supplies from Russia and other manufacturers, the change in their production structure and the features of organized gas exchange trading platforms in Russia are given.

As a result, it was revealed that the prospect of developing large-scale production and transportation of LNG in Russia should be based primarily on domestic developments and is an integrated state task. Such opportunity by 2018-2020 will complete the development of Russian technologies for the production of basic cryogenic equipment, as well as solve the tasks of implementing import substitution programs and improving the economic security of the country.

With regard to increasing the efficiency of exchange trading in gas, it is proposed to introduce new and improve existing gas indices.

Keywords—LNG; liquefaction; gas; prospects; export; supply: market.

\section{INTRODUCTION}

Until recently, the global gas market was based on longterm supply contracts that contained harsh conditions, directly depended on the price of oil or oil products before the ban on reselling gas to other consumers. In real geopolitical conditions, the situation on the gas market is rapidly changing. The slate revolution and the development of LNG technologies have led to significant transformations in regional energy balances, which have become the drivers for the implementation of complex trading operations on a global scale $[14,15]$.

The formation of the world gas market is also conditioned by large-scale LNG transport, which became possible through the creation and implementation of energy-efficient and economically efficient LNG production technologies with subsequent regasification, the construction of cryogenic largetonnage vessels of gas carriers. The advantage of liquefying natural gas is that this process, firstly, allows one to reduce gas volume 600 times; secondly, LNG shipments by tankers and cryotechnics are cost-effective compared to the supply of pipeline gas transport and the third, under geopolitical conditions becomes more economically safe business process $[1,2]$.

Also, the importance of world gas trade became stronger after the entry of new suppliers to the gas market and the increase in the supply of LNG from the US, Australia, Russia and Mexico, and led to the fact that buyers began to make decisions on the market, and suppliers only have to take into account their preferences.

\section{RESULTS AND DISCUSSION}

\section{A. Prospects for gas production and development of $L N G$ production}

According to forecasts [6], by 2035 the share of natural gas in the world energy balance will exceed $25 \%$, where LNG will be $13-16 \%$ of the total gas consumption if in 2016 this share was already $10 \%$.

Demand for energy resources continues to increase worldwide and accounts for $60 \%$ of growth since the early 1990s. In the face of stricter environmental requirements, consumers are more likely to use natural gas in general, including LNG. Over the past 25 years, the growth in demand for LNG as an energy carrier has been $2.3 \%$ per year.

The key factors characterizing the expansion of demand for natural gas (Fig.1) are:

- shifting priorities towards clean energy sources in both developed and developing countries (e.g. China);

- greater opportunities for supply of liquefied gas, allowing one to expand the trading logistics network in comparison with the pipeline transport of gas, which has significant geopolitical risks; 
- the ability to meet emerging gas demand during peak demand periods.

By 2005, the tendency towards globalization of the natural gas market began to be viewed, which was due to the positive dynamics of aggregate gas demand, the growth of capital investments in production and development and expansion of trade flows of gas exporters.

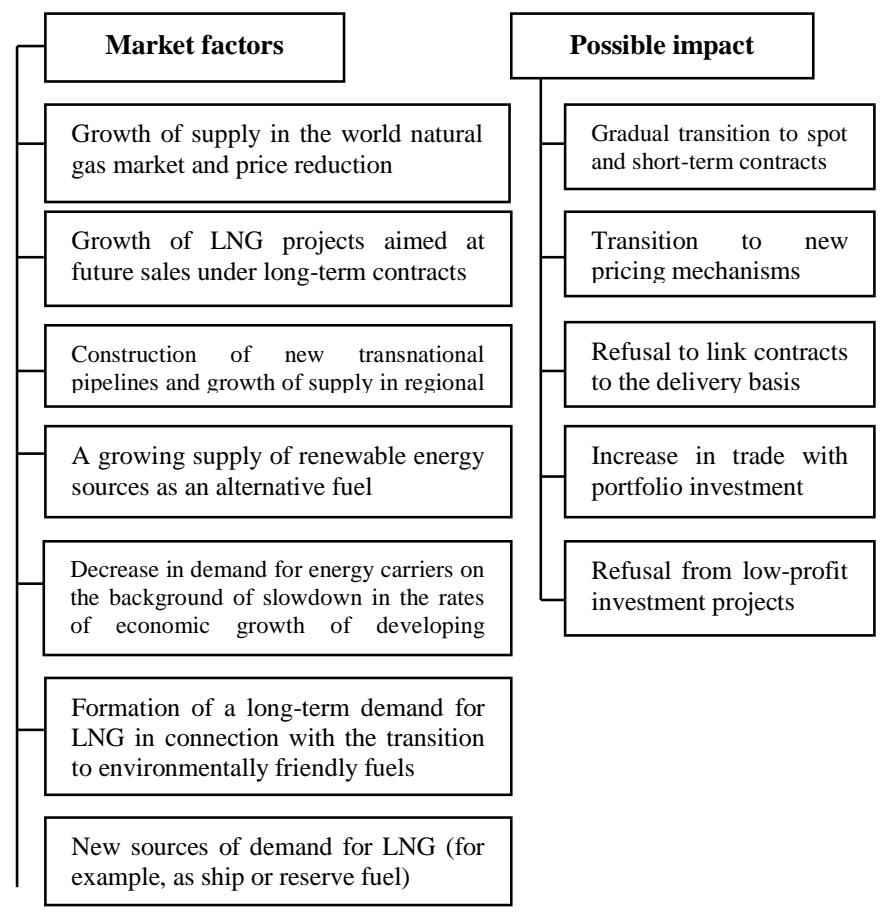

Fig. 1. Market factors and their possible impact on the LNG market

Russia continues to hold strong positions in world gas exports despite a decline in the share below 20\% in 20142015. The share of LNG in world trade is in the range of 30$32 \%$ (Fig. 2) [10-12].

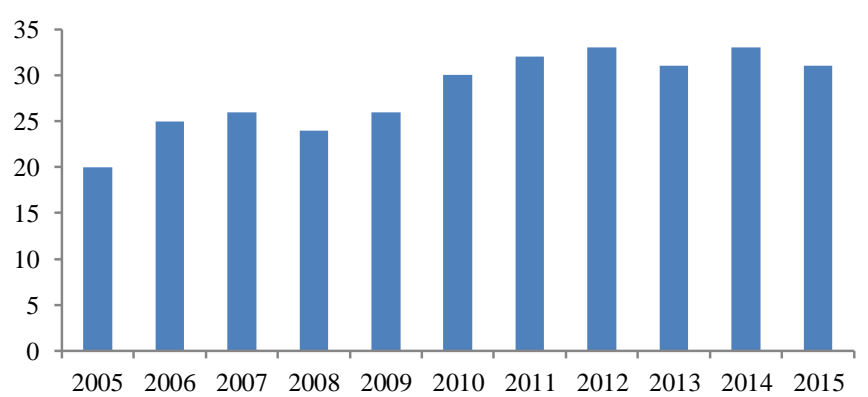

Fig. 2. LNG share in international gas trade, \% (Source: IEA)

The development of shale gas production can significantly change the situation on the world market of hydrocarbons [1012]. This is possible due to the use of American technologies of shale gas production in various regions of the world, allowing increasing the volumes and economic efficiency of extractive industries. For example, the export of technologies from the United States in the field of shale gas production, and the expansion of the liquefied natural gas market will allow a number of countries to enter major exporters and increase the world supply of gas several times. Shale gas producing countries include Argentina, Algeria, Australia, Brazil, Canada, Mexico, South Africa, and others (Fig. 3). The US is a net importer of gas, but plans to increase its production capacity to increase exports. Currently, the production and export of LNG in Russia is being implemented at the plant. Sakhalin, the installed capacity of production is 9.6 million tons per year with the actual increase in volume in 2012-2016 year up to 10.8 million tons per year, equivalent to about 14.7 bcm in gas equivalent.

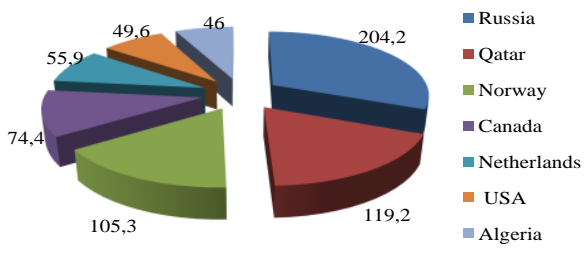

Fig. 3. LNG exports to the world gas market in 2015, bcm (Source: IEA)

The entire volume of liquefied natural gas is exported by sea to the APR countries, mainly to Japan, the Republic of Korea, Taiwan and China. Projects on the construction of new LNG plants are being implemented. So, in early December 2017 year the first technological line of the plant on Yamal Peninsula (Yamal-LNG project) with the capacity of 5.5 million tons per year was launched. The total production capacity of the plant is 16.5 million tons per year. It is also planned to commission the PJSC "Gazprom" plant in the Leningrad region "Baltic LNG".

For 2000-2016 years the geographical structure of gas exports from Russia has not undergone significant changes the main buyers are the countries of Europe (Fig. 4) [10-12].

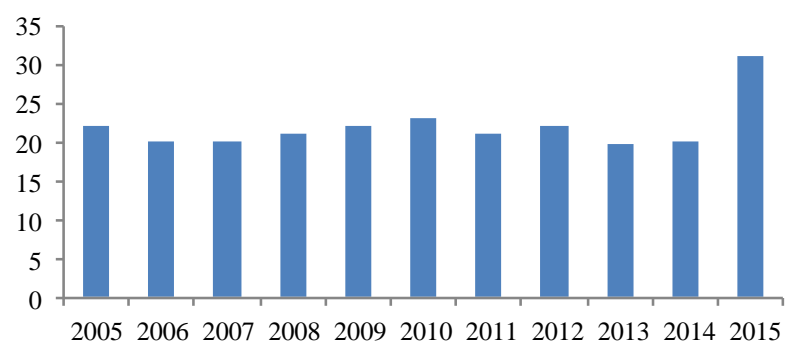

Fig. 4. Russia's share in international gas trade, \% (Source: IEA)

In 2009 year, together with the launch of the LNG plant on Sakhalin for Russian gas, a new market for the ATR opened. 
The main LNG supplies are to Japan and the Republic of Korea.

In 2016 [11], the eastern direction accounted for $7 \%$ (15 $\mathrm{bcm}$ ) of gas exports from Russia. Over half of the Russian gas exports were directed to four countries: Germany (23\%), Turkey (12\%), Italy (9\%) and Belarus (9\%). In 2016, Germany ( +6.2 bcm by 2015), Great Britain ( +6.5 billion $\mathrm{m} 3$ ) and France $(+1.8 \mathrm{bcm})$ provided the largest absolute increase in deliveries, significantly reduced the purchase of Russian gas Italy ( $-4.2 \mathrm{bcm}$ by 2015$)$ and Turkey $(-2.2 \mathrm{bcm})$. Ukraine in 2016 stopped direct gas imports from Russia after its sharp reduction in 2015.

According to forecasts [11], the APR and Europe remain the main market for the sale of Qatari LNG. The change in the structure of LNG supplies occurred in Qatar, which diversifies them at the expense of Pakistan, Argentina and the countries of North Africa (Fig. 5).

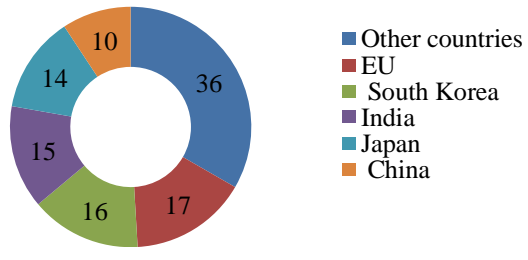

Fig. 5. Volumes of supply of Qatari LNG in 2017, bcm (Compiled by the author according to [8])

In the structure of LNG export from Qatar for 2017, the share of countries not belonging to the APR and Europe increased to $22 \%$ (+15 pp compared to 2014), while the share of supplies to the premium market of the ATR decreased to $63 \%$ ( $-7 \mathrm{pp})$.

The main consumers of natural gas are Pakistan, Argentina and the states of North Africa, where the demand for blue fuel is steadily growing. In the medium and long term, Qatar is actively developing new LNG sales territories and is in line with the strategy of increasing export volumes.

The increase in gas consumption in Pakistan is due to the development of domestic hydrocarbon production. So, at the end of 2017 year, the Pakistani state company OGDCL opened the 2nd deposit at the Baratai oil and gas block in the state of Khyber Pakhtunkhwa, which will cover these needs by $30 \%$ in oil and about $70 \%$ in gas. The rest is planned to be provided through imports, namely LNG supplies [12].

According to [12], LNG import to Pakistan increased more than 3 times in 2015-2017 against a background of falling production and growth in consumption. Completion of the construction of the regasification terminal by 6.8 billion cubic meters per year in 2015 allowed one to increase LNG import to Pakistan, whose deliveries for January-October 2017 amounted to $5.2 \mathrm{bcm}$ ( $+45 \%$ against the same period in 2016). The growth of imports is associated with the need to cover the gas deficit (production has fallen since 2012) in the electricity and agricultural sectors. By 2018, Pakistan plans to increase the regasification capacity to $12 \mathrm{bcm} /$ year, and by 2020 year to build a gas pipeline from Karachi to Lahore (the project is being implemented by the Rostek Group of Companies).

Considering the world trends affecting the development of energy markets at the present stage, ie. The reduction in prices for hydrocarbons, the reduction of own funds as profit as a resource base for investment of gas companies, the prospects for the development of the gas industry, both for the immediate period and long-term, become topical.

Estimates of the IEA and AEI forecasts of the development of the gas industry in Russia correlate with the baseline scenarios and suggest an increase in gas production by 20 $23 \%$ by $20-23 \%$ compared to 2016 year. The increase in consumption by 2040 year in the IEA forecast is expected to be $3 \%$, and according to the forecast The AEI of the United States will remain at the level of 2016 year. The probable increase in production is directly related to the increase in exports and the commissioning of major infrastructure projects: the Siberia-Siberia gas pipeline to China, the second and third phases of the Yamal LNG, the Baltic LNG and the Arctic LNG - 2. [4, 5].

According to analysts' forecasts [8,9], the development of interregional gas trade will be influenced by North American liquefied natural gas (LNG), which is in the long run the most demanded. This will depend on the development of the world's LNG industry, i.e. from the rates of shale gas production, the period of construction of export LNG terminals and in the future may strengthen the price regionalization of the hydrocarbon market, in particular natural gas.

So, according to Michael Denison, due to the increase in LNG supplies, the natural gas market is becoming global, the inter-regional pipeline network is growing, the pricing system that combines spot and long-term supply contracts is changing. This is facilitated by the following factors $[14,15]$ :

- prospects for gas production in a non-traditional way in North America, taking into account the improvement of gas supply and production drilling technologies;

- development of diversification of the world distribution of reserves of shale, dense gas and methane of coal seams;

- political changes in the consumption of hydrocarbons in Germany and Japan, with the transition from nuclear fuel to gas;

- possible use of the gas conversion mechanism in freight transport.

According to expert estimates [5], the forecast prices for natural gas in the world's major consumer regions have a positive trend (Table 1). The increase in global LNG consumption is due to the fact that at the beginning of 2018, there were 120 sea and river vessels $(0.001 \%$ of the world fleet) consuming LNG as the main fuel. Also there are ferries, merchant ships and tankers using fuel oil as fuel, and 111 ships are under construction [6]. 
TABLE I.

FORECAST PRICES OF NATURAL GAS IN REGIONAL MARKETS (DOLL/ $1000 \mathrm{M} 3$ )

\begin{tabular}{|c|c|c|c|c|c|c|c|}
\hline Countries & 2018 & 2019 & 2020 & 2021 & 2023 & 2025 & 2030 \\
\hline Europe & 204 & 208 & 215 & 222 & 233 & 247 & 286 \\
\hline USA & 111 & 115 & 122 & 125 & 136 & 147 & 179 \\
\hline Japan & 297 & 304 & 308 & 311 & 322 & 333 & 358 \\
\hline
\end{tabular}

a. Compiled by the author according to the [4].

According to the forecast of DNV LG analysts, by 2020 the number of ships operating on LNG will increase to 1,000 units. Also, the Oxford Institute for Energy Studies predicts that in 2030 more than $50 \mathrm{bcm}$ of gas will be used as fuel for bunkering ships compared to 2017 when less than $1 \mathrm{bcm}$ was consumed [6].

In the world market of the LNG industry, in particular bunkering of LNG tankers with the necessary infrastructure, there are three major ports: Rotterdam, Vancouver and Singapore (opened in September 2017 year). The level of development of the LNG industry in this area is at an early stage. It is planned that during the competition between ports in Europe, Asia and North America, the implementation of infrastructure projects will contribute to a steady increase in demand and supply for LNG bunker services [16].

The prospect of the development of large-scale production and transportation of LNG in Russia is based primarily on domestic developments and is a complex task. Such opportunity by 2018-2020 will be the completion of the development of Russian technologies for the production of basic heat exchange equipment and equipment for storage and transportation of LNG including cryogenic heat exchanging equipment of tubular type, transport cryogenic tanks, cryogenic pumping equipment, flexible cryogenic pipelines for LNG transportation, cryogenic pipelines with screenvacuum and vacuum insulation for transportation LNG. By 2020, it is planned to conduct industrial tests of the LNG plant based on domestic technology with mixed refrigerant. Technologies for the production of ice-class gas carriers, new ship propulsion systems, floating plants can be completed and introduced into production no earlier than in 2035 [6].

\section{B. Experience of international gas trade in Russia}

The next direction of development of the world gas market is the creation of a modern exchange trade in Russia. The domestic state policy in the field of development of economically justified competition in the natural gas supply market is realized through the introduction of foreign experience and the experience of related industries. One of the foremost areas today is the development of exchange trade in natural gas in the domestic market. Since 2008, Russia's exchange trade in gas is carried out at the St. Petersburg International Commodity Exchange (SPMMEX) [8,9].

In 2018, 75 companies took part in the SPMEX [7], including 31 permanent participants, the remaining 44 - with a limited period, 21 companies are part of the existing marketing network of PJSC Gazprom and, in particular, LLC «Gazprom Mezhregiongaz». These companies are represented mainly by the European part of Russia. Trades are carried out on the resources of four compressor stations (KS) / balance points: KS Nadym, KS Vyngapurovskaya, KS YuzhnoBalykskaya, KS Parabel. The results of exchange trades in gas are presented in Table 2.

TABLE II. NATURAL GAS PRODUCTION AND PIPELINE EXPORTS IN RUSSIA

\begin{tabular}{|l|c|c|c|l|l|l|l|}
\hline \multicolumn{2}{|c|}{ Gas production } & \multicolumn{2}{|c|}{ Gas export } & \multicolumn{2}{c|}{$\begin{array}{c}\text { Gas index } \\
\text { SPbMTSB }\end{array}$} & \multicolumn{2}{|l|}{$\begin{array}{c}\text { Volume of } \\
\text { exchange trade }\end{array}$} \\
\hline Jan.- & $\%$ of & Jan.- & $\%$ to & Dec. & $\%$ of & Jan.- & $\%$ of \\
Dec. & Jan. - & Nov. & Jan.- & 2017, rub. & Nov. & Dec. & Jan.- \\
2017 & Dec. & 2017 & Nov. & /thous. $\mathrm{m}^{3}$ & 2017 & 2017 & Dec. \\
bcm & 2016 & bcm & 2016 & & & 2016 \\
\hline 690,9 & $+8,1$ & 179,8 & $+1,0$ & 3179 & $-1,2$ & 20,4 & 21,5 \\
\hline
\end{tabular}

In December 2017, gas production in Russia decreased by $3.8 \%$ by December 2016 . This could be caused by favorable weather conditions in December in most of the country. In general, in 2017, gas production increased by $8.1 \%$ by 2016 and reached $690.9 \mathrm{bcm}$, which is a record indicator for the post-Soviet period. The total trading volume at SPIMEX (at all balance points) for 2017 was $20.4 \mathrm{bcm}(+21.5 \%$ by 2016). The largest deviation between the price at the exchange (at the Nadym compressor station) and the regulated wholesale price (table 3) for gas was observed in the Sverdlovsk region $(-7.3 \%$ to the regulated price) Fig. 6. [7].

TABLE III. AVERAGE PRICE OF GAS SALES

\begin{tabular}{|c|c|c|c|c|c|c|c|c|c|}
\hline \multirow[b]{2}{*}{ Period } & \multicolumn{3}{|c|}{ Russia } & \multicolumn{3}{|c|}{ Far abroad } & \multicolumn{3}{|c|}{ Countries of the FSU } \\
\hline & $\begin{array}{l}\mathrm{rub} / \\
1 \text { thous } \\
\mathrm{m}^{3}\end{array}$ & $\begin{array}{l}\text { doll/ } \\
1 \\
\text { thou } \\
\mathrm{s} \mathrm{m}^{3} \\
\end{array}$ & $\begin{array}{l}\text { euro } \\
l \quad 1 \\
\text { thou } \\
\mathrm{s} \mathrm{m}^{3} \\
\end{array}$ & $\begin{array}{l}\text { rub / } 1 \\
\text { thous } \mathrm{m}^{3}\end{array}$ & $\begin{array}{l}\text { doll/ } \\
1 \\
\text { thou } \\
\mathrm{s} \mathrm{m}^{3} \\
\end{array}$ & $\begin{array}{l}\text { euro / } \\
1 \text { thous } \\
\mathrm{m}^{3}\end{array}$ & $\begin{array}{l}\mathrm{rub} / \\
1 \text { thous } \\
\mathrm{m}^{3}\end{array}$ & $\begin{array}{c}\text { doll/1 } \\
1 \\
\text { thou } \\
\mathrm{s} \mathrm{m}^{3} \\
\end{array}$ & $\begin{array}{l}\text { euro } / 1 \\
\text { thous } \mathrm{m}^{3}\end{array}$ \\
\hline 2012 & 2868 & 92 & 72 & 11969 & 385 & 299 & 9489 & 305 & 238 \\
\hline 2013 & 3265 & 102 & 77 & 12138 & 381 & 286 & 8499 & 267 & 201 \\
\hline 2014 & 3507 & 91 & 69 & 13487 & 349 & 265 & 10116 & 262 & 198 \\
\hline 2015 & 3641 & 59 & 54 & 15057 & 246 & 222 & 11911 & 194 & 175 \\
\hline 2016 & 3816 & 57 & 52 & 11763 & 176 & 159 & 10263 & 154 & 139 \\
\hline
\end{tabular}

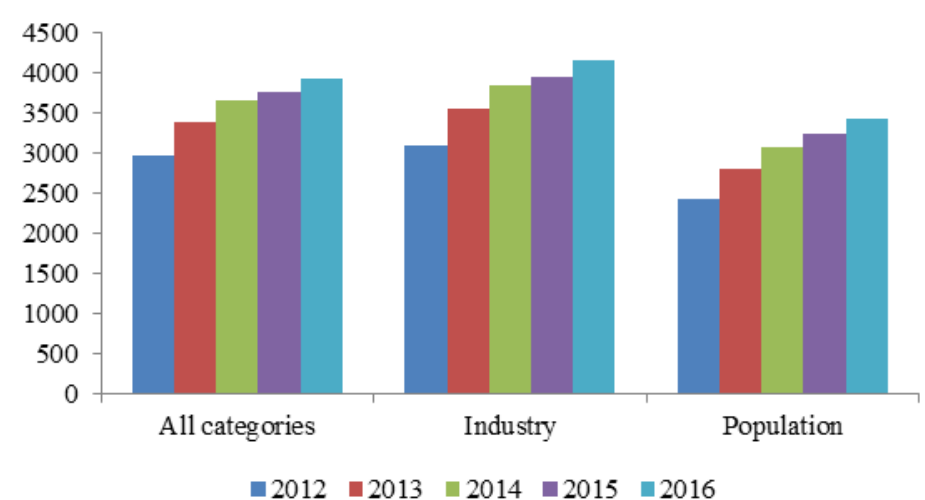

Fig. 6. Weighted average wholesale regulated gas prices in Russia, $\mathrm{rub} / 1000 \mathrm{~m}^{3}$ 
With the launch in October 2014 of the gas index at the St. Petersburg International Commodity Exchange, liberalization of Russia's domestic gas market became possible. For five months of 2016, the volume of exchange trading in gas increased fivefold as compared to the same period in 2015. The gas field in Russia is at an early stage of development compared with the level of development of the gas exchange indices Henry Hub in the US and NBP in the UK. The opening of the Russian gas index was preceded by Resolution No. 323 of the Government of the Russian Federation of 16.04.2012, providing for the regulation of gas prices on the domestic market, access to the gas transportation and gas distribution system of Gazprom (GTS), and the sale of natural gas on the commodity exchange [7]. The creation of exchange gas trading in Russia was to solve two long-term tasks of the domestic market:

- replacement at exchange prices regulated in long-term contracts by achieving equal yields of supplies and the abolition of cross-subsidization;

- the formation of a transport tariff based on the creation of a transparent system, established by the FAS Russia in a cost-effective manner by analyzing the reporting of PJSC Gazprom.

The implementation of these tasks will make it possible to stagnate in the gas industry, its dynamic development in the long term and enhance the competitiveness of Russian gas both on the domestic and foreign markets.

According to SPbMTSB, as of May 2016, the difference in the price level for the gas sold was $9.8 \%$, which contributes to the growth of demand for exchange contracts and may lead to the need for long-term gas contracts and stock indices by refusing regulated prices [9].

All gas indices within the framework of vertically integrated companies (VIC) and independent gas producers (NPG) undergo the same stages of development, outstripping in the sphere of gas transportation and sales or a competitive market (Table 4) [3].

TABLE IV. ESTABLISHMENT OF THE INTERNAL GAS MARKET

\begin{tabular}{|c|c|c|c|}
\hline \multirow[b]{2}{*}{ Gas sectors } & \multicolumn{3}{|c|}{ Stages of formation } \\
\hline & $\begin{array}{c}\text { VIC } \\
\text { domination }\end{array}$ & $\begin{array}{c}\text { VIC control } \\
\text { over the GTS } \\
\text { and dominance } \\
\text { in marketing }\end{array}$ & $\begin{array}{c}\text { Competitive } \\
\text { market }\end{array}$ \\
\hline $\begin{array}{c}\text { Gas } \\
\text { production }\end{array}$ & VIC & VIC and NPG & NPG, VIC \\
\hline $\begin{array}{c}\text { Transportati } \\
\text { on of gas }\end{array}$ & VIC & VIC & $\begin{array}{c}\text { Independent } \\
\text { transport } \\
\text { company }\end{array}$ \\
\hline Timing & VIC & VIC & $\begin{array}{c}\text { Independent } \\
\text { gas distribution } \\
\text { company }\end{array}$ \\
\hline Gas sales & VIC & $\begin{array}{c}\text { VIC and NPG } \\
\text { (insignificant } \\
\text { volumes) }\end{array}$ & $\begin{array}{l}\text { Trading through } \\
\text { stock exchange }\end{array}$ \\
\hline
\end{tabular}

Expansion of exchange gas trade in Russia and the positive dynamics of its development is hampered by continued control over the gas transportation system and sales, which is located at the vertically integrated companies (VIC). An example of and an important factor in the development and growth of the volume of exchange trade in petroleum products in Russia is the creation of an independent transport company - Public Joint Stock Company PJSC Transneft.

The most advanced gas indices are the Henry Hub index in the US and the NBP index in the UK, which passed the main stages of the competitive market development.

For example, in the international gas trade in December 2017, there was a tendency for the decrease in spot gas indices in the US and Europe, against the backdrop of an increase in natural gas prices in Asia [4]. In Japan, the decline in the spot LNG index reached 362 doll per thousand. $\mathrm{m} 3$ (+ 3.6\% by November 2017), while the index-indexed JCC on the contrary increased to 297 doll / thous. $\mathrm{m} 3$ (+ 4\%). The growth trend of spot prices in Asia is associated with an increase in demand for natural gas in China and the growth of JCC with a gradual increase in oil prices. The decline of the American Henry Hub index to 96 doll / thous is noted, m3 (-7.5\%), and this is due to an increase in the extraction of shale gas. The European TTF declined slightly $(-1.4 \%)$ to 258 doll / thous $\mathrm{m} 3$.

\section{CONCLUSION}

Currently, the LNG industry is one of the most important and relevant areas for the development of international trade in natural gas.

The ongoing changes in the LNG market have a significant impact on the business processes of all participants in international trade from producers to end users. In the world market, the growth in supply of LNG changes the ratio of demand in favor of buyers. These structural changes in the demand and supply of the LNG product on the world market will contribute to the development of international trade through the emergence of new trading floors and hubs. Also, market participants will have to make serious investment decisions in the face of greater uncertainty about pricing [13]

The main criterion for the sustainable development of the world market for key LNG producers is the increase in the efficiency of existing production capacities. It requires the development of new marketing strategies that allow for effective sales after the expiration of long-term contracts. In complex geopolitical conditions, the implementation of new investment projects of the LNG industry should be characterized by a high degree of resistance to price changes and minimum payback periods $[8,9]$.

In the course of the analysis of foreign indices, the problems of the development of the Russian gas index at the SPBMSEX exchange were revealed: a limited number of participants lead to a decrease in exchange trades and the future development of the exchange. The imperfection of the formation of tariffs for the use of the gas transportation system creates an incorrect formation of prices for associated petroleum gas, reducing trading volumes. Lag in the development of a competitive market is due to the lack of an independent transport company and the involvement of new 
potential consumers and producers. Reduction of exchange supplies in the physical market is due to the lack of a virtual gas market for futures supply and hedging of risks $[3,4]$.

\section{References}

[1] Y. Adzhiev, and P. Purtov, "Preparation and processing of associated petroleum gas in Russia: scientific publication", Krasnodar: ADVI., 2014, p. 776.

[2] Y. Dynarski, "Basic processes and apparatuses of chemical technology: teaching in the expedient design", Moscow: Publishing house Alliance, 2007, p. 328.

[3] Analytical center under the Government of Russia, "New forecasts of the world Energy and the place of Russia in it",. Energy bulletin, November 2017, p. 29.

[4] Analytical center under the Government of Russia, "The development of competition in the gas markets",. Energy bulletin, June 2016, p. 32

[5] Federal state statistics service of Russian Federation, 2017, retrieved from http://www gks.ru/ wps/wcm/connect/rosstat_main/rosstat/ru/statistics/publications/catalog

[6] ERI RAS and Analytical center under the Government of Russia, "Forecast of energy development in the world and Russia until 2040", 2014, retrieved from https://www.eriras.ru/files/forecast 2040.pdf
[7] Gazprom corporate analytical deaprtment, "Gazprom in Figures 2012 2016 year", 2017, retrieved from http://www.gazprom.ru/

[8] Enerhy analytical center, "The fuel and energy complex of Russia. 20052014”,. Information-analytic review, 2015, p. 452.

[9] Analytical center under the Government of Russia, "The development of competition in the gas markets", Information-analytic review, 2017, p. 58

[10] Novatek corporate analytical deaprtment, statistical report, 2018 , retrieved from http://www.novatek.ru/ru/

[11] Analytical center under the Government of Russia, "The strategy of innovative development of the Russian Federation up to 2020", 2014 retrieved from http://ac.gov.ru/files/attachment/4843.pdf

[12] The Ministry of energy, Official report, 2017, retrieved from https://minenergo.gov.ru/activity/statistic

[13] E. Dekonst, "The oil and gas industry of Russia", 2017, retrieved from http://fb.ru/article/263751/neftegazovaya-otrasl-rossii

[14] L. Vazhenina, "Associated petroleum gas: experience of processing and performance evaluation", Tyumen: Tyumen oil and gas University, 2011, p. 216.

[15] L. Vazhenina, "Formation of mechanisms for the development of energy saving and energy efficiency in the gas industry", Tyumen: Tyumen oil and gas University, 2017, p. 186.

[16] M. Young, “The Technical Writer's Handbook", Mill Valley, CA: University Science, 1989. 